\title{
Clinical Trial Subject Information Form
}

National Cancer Institute

\section{Source}

National Cancer Institute. Clinical Trial Subject Information Form. NCI Thesaurus. Code C115517.

Documentation given to a subject to provide instructions or information related to the trial. 